Revue de littérature générale et comparée

Résister à la littérature

\title{
Inner and Outer Resistance to China: The Pursuit of Freedom in A Free Life and The Dark Road
}

\author{
Martina Codeluppi
}

revues.org

Publisher

Presses Sorbonne Nouvelle

Electronic version

URL: http://trans.revues.org/1358

ISSN: 1778-3887

Electronic reference

Martina Codeluppi, «Inner and Outer Resistance to China: The Pursuit of Freedom in A Free Life and The Dark Road», TRANS- [Online], | 2016, Online since 27 October 2016, connection on 08 November 2016. URL : http://trans.revues.org/1358

This text was automatically generated on 8 novembre 2016 .

Tous droits réservés 


\title{
Inner and Outer Resistance to China: The Pursuit of Freedom in A Free Life and The Dark Road
}

\author{
Martina Codeluppi
}

Refusal has always been an essential gesture. [...] The few who made history are those who said no.

Pier Paolo Pasolini ${ }^{1}$

1 many domains, among which literature can be regarded as one of the most prolific. Nevertheless, political power and literature have always been interrelated, and when a Government exiles its own citizens because of their literary dissidence, fiction can become an even more powerful weapon. This is the case of Ma Jian 馬建 (b. 1953) and Ha Jin 哈金 (b. 1956), Chinese authors currently exiled in the United Kingdom and the United States respectively. Their personal protests against the Motherland took different shapes, being expressed by means of either a strong accusation or a silent refusal. These authors' works were compared and juxtaposed by Belinda Kong ${ }^{2}$ and Peter Damgaard, ${ }^{3}$ mainly with reference to their novels dealing with the Tian'anmen Square protests of 1989: Ma Jian's Beijing Coma ${ }^{4}$ and Ha Jin's The Crazed. ${ }^{5}$ These studies served as a background for the following investigation, which envisages a comparison between the authors' different interpretations and fictional representations of resistance. This inquiry was conducted on Ma Jian's The Dark Road ${ }^{6}$ and on Ha Jin's A Free Life: ${ }^{7}$ two stories that develop following their protagonists' conflict against their own country, reflecting the complexity of an interiorised struggle between the individual and power.

3 Moving from Foucault's reflections on power and resistance, the authors' different ways to resist to the Motherland were analysed and compared as they were expressed through their literary creation. The concept of anti-authority struggle ${ }^{8}$ was applied here at two levels, following the two interpretations of authority understood as political power, 
namely that of Mainland China, and as psychological reflection of a questioned ethnical identity. How do these authors resist to the Motherland? To what extent does this opposition to the P.R.C. constitute the lifeblood of their creation? How is this this perpetual friction embodied in their novels? In order to answer these questions, this paper will first address the issue of the authors' personal opposition to China. It will then explore how their internalised conflicts are revealed through the narratives, providing insights on the relationship between the multifaceted identity of the exiled individual and its literary re-elaboration.

\section{Exiled from the Motherland, Tied to the Mother Tongue}

4 The origins of Chinese 'diaspora literature' can be traced back to the first decades of the $20^{\text {th }}$ century. However, the phenomenon reached a new dimension after Deng Xiaoping's political reforms of the 1980s and especially after the Tian'anmen protests of 1989 , the military repression of which caused the exile of many intellectuals. ${ }^{9}$ Ma Jian and Ha Jin are two amongst the most important authors of contemporary 'Overseas Chinese literature,' whose voluntary departure from Mainland China resulted later in an actual banishment by the government. These writers' subversive attitude is a fundamental trait of their works, nevertheless, despite their common status of exiled individuals, the two authors have shaped their relationship with the Motherland in extremely different ways.

Ma Jian left China for Hong Kong in 1987 and, after the P.R.C. resumed its control on that area in 1997, he moved first to Germany and later to the United Kingdom, where he currently lives with his wife and translator Flora Drew. During the years abroad, Ma Jian occasionally flew back to the Mainland and it should be noted that he was in Beijing during the student movement that ended with the military crackdown of June $4^{\text {th }} 1989 .{ }^{10}$ However, in 2011, after the publication in Taiwan of his highly political novel Beijing Coma, Ma Jian was prevented from entering China, becoming officially an exiled author. Jin Xuefei 金雪飛, better known by his nom de plume Ha Jin, after serving in the Popular Liberation Army for several years, emigrated to the United States in 1985 to pursue a Ph.D. in English literature. Although he had planned to eventually return to China, the Tian'anmen events - which he followed at a distance - made him decide to stay in the U.S. for the rest of his life, confining himself to a foreign land and a foreign language. ${ }^{11}$ He has never returned to his motherland because in 1997 the authorities refused to renew his passport, after he became a persona non grata to the Chinese government. Later, they also prevented him from entering the P.R.C. as an American citizen. Both these authors put up a sort of fight with China, the consequences of which affected not only their lives, but also their literary production, which is permanently related to their subversive identities.

6 Besides the overt political denouncements, Ma Jian's and Ha Jin's resistance to China affects their creations at a deeper level, resulting in a complex psychological mechanism. Foucault, in his essay "The Subject and Power," postulated three types of struggle: against forms of domination; against forms of exploitation; or against "that which ties the individual to himself and submits him to others in this way." ${ }^{12}$ The 'power' that these authors resist can be identified as China, yet this is a general term that implies at least two different interpretations: a political authority, and a cultural and ethnical identity. Therefore, the struggle that they undertake is multiple, both against a form of domination by a controversial government and against an extra-politic force imposed on 
the individual. The effect of this double force is reflected, for example, in their choice of language.

7 Ma Jian openly condemned the Chinese authorities' control over literature, emphasising how their despotism hinders the development of the individual, hampering literary creation itself: "Style is personal character, and a regular free society guarantees its existence." ${ }^{13} \mathrm{He}$ accused mainland writers of becoming "mute" because of the state's ideological pressure and pointed out how, as a result, their literature is incapable of expressing the "author's soul."14 Despite fleeing the censorship by writing and publishing abroad, Ma Jian could not cut ties with his mother tongue, which remained his unique means of expression. He continues to write in Chinese, publishing his works - banned in the P.R.C. - in Taiwan and Hong Kong, while counting on a close collaboration with his translator for their international circulation..$^{15}$ Such a 'compromise' is essentially an impasse: his personal opposition to China is bound to be voiced by means of a language that has been concretely shaped by the very same power he wants to resist. ${ }^{16}$

Contrariwise, Ha Jin decided to devote himself to writing in English, after the Tian'anmen massacre triggered his refusal of his own country: “I wouldn't let the Chinese state power shape my existence anymore [...]. To preserve the integrity of my work, and to separate my existence from the powers that be, I could not but write in English." ${ }^{17}$ Yet, turning his back on his mother tongue was not a decision he took light-heartedly. As Ha Jin pointed out in his essay "The Language of Betrayal," it was a risky and painful choice made out of necessity, in order to be able to survive and pursue his own vision. ${ }^{18}$ Despite the threat of failure, he chose to channel his creative energy into a foreign language as a crucial act of resistance; nevertheless, he was never really able to 'separate' himself from Chinese, which he kept insinuating subtly into the fabric of his linguistic expression.

9 According to Foucault, "[t]he problem is not to try to liberate the individual from the state, and from the state's institution, but to liberate us both from the state and from the kind of individualization which is linked to the state." ${ }^{19}$ Language plays an essential role in the definition of an individual; when the state exercises its ideological and coercive power over it, as in the case of Chinese government, the individual and the state, incarnated in his own language, become two entities difficult to disentangle. Although this is clearly a paradoxical situation; since the Chinese language is not 'owned' by any political power, it would seem that these authors, no matter whether they chose to employ their mother tongue or not, are permanently connected to the Chinese language. Like an umbilical cord that, regardless of the spatial and ideological distances, always reaches them, unceasingly nourishing their literary expression.

\section{The Dark Road and A Free Life}

10 Ma Jian's and Ha Jin's resistance to their motherland is not only a mission, or a source of inspiration, but it is also a theme, concretely embodied in their works. The following analysis of the novels The Dark Road and A Free Life will emphasise how these authors' personal fights contributed to shaping their literary creation, revealing how their internal struggles are represented in their texts.

11 The Dark Road is a novel set in rural China during the 1990s, at the time of Jiang Zemin's leadership. It tells the story of the young Meili who, after having given birth to the little Nannan, gets illegally pregnant for the second time. In order to escape the family 
planning officials, she leaves her village, together with her husband Kongzi, $76^{\text {th }}$ descendant of Confucius, and their little daughter, engaging herself in the desperate search of a safe place in which to give birth to her child. Floating on the Yangtze river, Meili and her family move along the water arteries of China, trying to reach Heaven Township, a town so polluted with electronic waste that its air is believed to neutralise women's fertility. During her maternity odyssey, Meili falls pregnant three times, facing each one of them side by side with the infant spirit, which repeatedly tries to come to life, yet without succeeding. The first baby survives a forced abortion and is heartlessly killed by the authorities; the second one, a baby girl who was born deformed, is sold away by her father for uncertain purposes; and the third one never finds the courage to exit her mother's womb. The imaginary character of the infant spirit is created by the author to represent the spirit of life, whose mission is to incarnate in the body of the baby. Ma Jian's fictional creation is also a powerful narratological tool, as it provides an external point of view that occasionally takes the lead of narration, enriching it with its "eyeless point of view". ${ }^{20}$ Besides the strong denunciation of the One-Child Policy, in this novel Ma Jian explores the social and personal consequences of the Government's intrusion to intimately feminine issues, showing undeniable empathy with some feminist principles. ${ }^{21}$

12 A Free Life narrates the vicissitudes of the Chinese immigrant $\mathrm{Nan} \mathrm{Wu}$ chasing his American dream, after his family reunites in the United States in 1989. Having been involved in the attempted organisation of a subversive reaction to the Tian'anmen massacre, Nan's passport is revoked and he is prevented from returning to China. Since his disenchanted spirit led him to abandon his Ph.D. in Political Science, Nan reinvents himself as a chef, cultivating in parallel his passion for poetry and for the English language, which he studies devotedly. On choosing to be an immigrant, not an exile, the protagonist is able to translate the banishment from his motherland into an opportunity to build a new life in a free country. Nevertheless, China is deeply rooted into Nan's identity and no matter how hard he tries to detach himself from it, it keeps taking possession of his mind. This is noticed especially through the character of Beina: the woman who broke his heart and with whom Nan is still in love. It is not until he manages to return to his homeland for a short trip that Nan realises the profound mutation of his personality and recognises his new American identity. In depicting the struggles of Chinese immigrants, Ha Jin portrays the identity crisis of the individual torn between old and new lands, ${ }^{22}$ exploring the complex mechanisms behind one's refusal of their own country.

13 Caygill pointed out in 2013 how resistance and freedom are two intertwined concepts, as the resistant subject is never free. Unable to enjoy the freedom of possibility, he is bound to resist chance. ${ }^{23}$ A Free Life and The Dark Road are precisely the narrations of two journeys undertaken by two families that struggle to resist China and to pursue their own freedom. Chinese political powers and their conflictual identities are the forces that the protagonists oppose, facing step by step the consequences of fate in a perpetual process of readjustment. The temporal and spatial progression in which the two stories develop emphasises the evolution of the characters' resistance, showing how "the capacity to resist does not occupy a punctual present, but it is strung between past and future." ${ }^{24}$ 


\section{Fictionalising Resistance}

14 The two novels represent two scenarios of resistance to China, created by two authors which embody two different kinds of resisting individuals. The connection between the writers and the products of their refusal of the motherland can be better understood using Foucault's intuition that power is not an outside-entity: power relations are immanent and therefore characterised by an undeniable heterogeneity. ${ }^{25}$ China, seen as a macro-entity of power, takes different shapes, influencing both the social life and the inner self of the authors. Similarly, it is represented in the novels on different levels, and the protagonists themselves fight it in its multiple incarnations. In Ma Jian's The Dark Road, it is possible to detect three main resisting subjects: Meili's family, which struggles against the brutality of family planning officials; Meili herself, who fights patriarchal society represented by her husband and his obsession for a male heir; and the infant spirit, which is repeatedly prevented from incarnating, first by a murderer society, and eventually by the foetus that refuses to come to life:

The infant spirit watches the foetus curl up with fright. When it was expelled from Mother's ovary and rolled down the fallopian tube at the beginning of this third incarnation, it was aware of the two previous times it had made this journey. It remembered Mother screaming: 'Don't come out into this world, my child! Return to me in another incarnation. Murderers! Animals! ...' Then, when it reached the womb and was penetrated by Father's sperm, memories from its former lives returned with greater clarity. [...] It realised it would have to choose between the poisons of the womb and the hostility of the outside world. The foetus isn't sure what lies outside, but is certain now, after taking a brief look, that this isn't its rightful birthplace. ${ }^{26}$

15 Not only are these dimensions of resistance interrelated, they even contain one another, exemplifying how the immanence of power brings resistance to develop also inside power itself. ${ }^{27}$ In A Free Life, the multiple representations of opposition to power are embodied in the same individual, namely the protagonist $\mathrm{Nan} \mathrm{Wu}$. He struggles against his mother tongue, which he needs to overcome in order to fully establish himself in the United States; against his feelings for Beina, the woman who represents his past and his unattained Chinese happy ending; and against a national identity that does not feel like it belongs to him anymore:

"You shouldn't have said that."

"Said what?"

"We have nothing to do with China."

"I know," he sighed. "I was just angry. If only we could squeeze the old country out of our blood."

Nan had once thought they could dissociate themselves completely from the Chinese community here and just live a reclusive, undisturbed life, but now it was clear that China would never leave them alone. Wherever they went, the old land seemed to follow them. ${ }^{28}$

The contraposition between old and new, past and future, is a theme common to the two novels, epitomising a key feature of both narrations: the process of changing. For Nan, this dichotomy is represented in the choice of language that brings him to cut ties with Chinese, which belongs to his past. He must accept the challenge to write his poetry in a foreign language, facing the possibility of failure and an uncertain future:

In Nan's case, it was clear that writing in Chinese would lead him to a dead end.

Could he do it in English? The same old question again tormented him these days. 
He knew that to him Chinese meant the past and English the future, the identification with his son. He also understood that by adopting another language he might wander farther away from his Chinese heritage and have to endure more loneliness and run more risk; eventually he might have to estrange himself from his mother tongue, in which a writer of his situation, in fact all writers in the Chinese diaspora, would be marginalized. But to write poetry in English was like climbing a mountain with a summit he couldn't see or envision. It was very likely that he might mess up his life without getting anywhere. Still, was there another way if he was determined to write? ${ }^{29}$

Similarly, because of her second pregnancy, Meili is forced to leave her harmonious past life in order to achieve a safe future for her family. Nevertheless, the traits of that future keep transforming along with the succession of events, all of them spinning together with the woman's tortured maternal instinct:

Now she is Kongzi's wife. For his sake, she left the village designated on her residence permit and the comfort of their tiled-roofed house. She'd dreamed that if she worked hard, she could open a shop one day and buy a modern apartment in a county town with a flushing toilet and hot shower, like the one owned by Cao Niuniu, the son of Kongzi's artist friend, Old Cao. She still believes that as long as she avoids another pregnancy, she'll be able to live a good life one day, and stroll along supermarket aisles wearing nylon tights and high-heeled shoes. ${ }^{30}$

If she gives birth to Heaven, she will leave Kongzi, save enough money to pay the family planning fine, then move back to Nuwa Village with her two daughters. [...] Yes, Kongzi can go to hell! I'm twenty-eight today. My best years are still ahead of me. I'll struggle on and make my way back to my place of birth, like the sturgeon that swim up the Yangtze. I won't let you die, Heaven. Whatever the future holds, we will withstand it together... ${ }^{31}$

Despite the divergences in the protagonists' paths, Nan Wu and Meili share the ultimate aim in their tormented lives: to gain independence. For Nan, this means to "discard the baggage of China" and to succeed in rebuilding a new life after having become a "country-less man," ${ }^{32}$ while Meili dreams of freeing herself from her status as a fugitive, building a career of her own and becoming "a person who not only has a body, but also a mind capable of thought." ${ }^{33}$ Resisting the motherland becomes here a necessary prerequisite for the construction of the individual. This recalls Foucault's thoughts on the aesthetic of the self, which is seen as nothing other than resistance, since modern power constitutes the individual as a subject, leaving no space for other forms of subjectivity. ${ }^{34}$ Nevertheless, the stories of the two characters' struggles are bound to different epilogues. After five years of pregnancy, Meili gives birth to a motionless baby, "green and shiny as an apple," 35 before drowning it in the river and releasing the infant spirit, which travels back to her place of birth to be reunited with her mother's soul. Contrariwise, Nan finds his freedom on recognising that his American dream was not to be realised, but that it was "something to be pursued only," ${ }^{36}$ in order to gain the courage to devote his life to writing poetry. Moreover, when Nan has the chance, after many years, to meet Beina again, he surprisingly dislikes her, "who had changed so much, or was so different from whom he'd imagined, that she had shattered his vision of her." ${ }^{37}$ Exactly like China itself. Only at that moment is he able to completely overcome his obsession with his exgirlfriend, and to open his heart to his wife Pingping, the personification of a new life in the United States. 


\section{Power is Resistance, Resistance is Power}

19 For Foucault, modern power is dispersive, and develops by means of intertwined relations of power, every one of which creates - by the mere fact of existing - the possibility of a resistance. ${ }^{38}$ Consequently, there is a multiplicity of resistances, constituting the opposite poles to power relations, which are manifested on different levels. ${ }^{39}$ Ma Jian and Ha Jin embody two manifestations of a resistance to the motherland, which they voice using different strategies. Ma Jian openly condemns the cruelties of China and the Communist Party; however, he cannot let go of his mother tongue. Inversely, Ha Jin adopts a more detached perspective and chooses to write in English for the sake of his freedom of expression. Yet, their resistance is not merely a political denunciation, it became a part of their individuality, tying them indissolubly with the power they fight. Ha Jin's and Ma Jian's opposition to their Motherland made them two spokesmen of their generation, who reveal in their novels their different approaches to this refusal.

A Free Life and The Dark Road exemplify the multifaceted relationships between the subjects and the powers, as they are nestled within the characters' selves. In A Free Life, the resistances are represented as a number of contrasting forces interiorised in Nan Wu's inner conflict with his language, his feelings, and his country. In The Dark Road, they are revealed through a number of struggling individuals that face power on different levels, from the intimate to the universal: the infant spirit against the woman's body, Meili against the patriarchal society, and the family against the state. For Nan Wu, the conflict between his Chinese self and his American self takes twelve years to resolve, and it is also thanks to this tension that the protagonist succeeds in actually becoming a free man. On the other hand, the infant spirit and Meili struggle on against the quintessence of biopolitical power, trying to defend their rights to life and to freedom, throughout eight years of fleeing. Nonetheless, the pressures that Meili must withstand are the very engine of her Bildung, bringing her to complete her maturation and to conceive the desire for a life she never knew she could imagine.

The power of China, both in its real manifestation and in its fictional representation, necessarily creates resistances, embodied in resistant subjects whose existence is paradoxically dependent on that of the power they oppose. In the case of Ma Jian and Ha Jin, Foucault's idea of an ontological correlation between power and resistance ${ }^{40}$ is therefore concretised, in the authors' individuality as well as in their literary expression.

\section{BIBLIOGRAPHY}

BROSSAT Alain. "Résistance(s) et pouvoir(s) chez Michel Foucauld [sic]" (Resistance(s) and power

(s) for Michel Foucault). In Résistances et transferts, edited by Patrick Chemla, 115-19, 2004.

CAYGILL Howard. On Resistance: A Philosophy of Defiance, London and New York: Bloomsbury, 2013. 
COLOMbo Furio, and ferretti Gian Carlo. L'ultima intervista di Pasolini (Pasolini's last interview), Roma: Avagliano, 2005.

DAMGAARD Peter. “Visions in Exile. Inroads to a 'Counter-System' of Contemporary Chinese Literature," Literature, University of Copenhagen, Faculty of Humanities, 2012.

FOUCAULT Michel. "La volonté de savoir" (The will to knowledge). In Histoire de la sexualité, vol. 1, Paris: Gallimard, 1976.

“The Subject and Power." In Michel Foucault: Beyond Structuralism and Hermeneutics, 208-26, Chicago: The University of Chicago Press, 1982.

GONG Haomin. "Language, Migrancy, and the Literal: Ha Jin's Translation Literature." Concentric: Literary and Cultural Studies 40, no. 1 (2014): 147-67.

HELLER Kevin. "Power, Subjectification and Resistance in Foucault." SubStance 25, no. 1 (1996): 78110.

HODGE Bob, and LOUIE Kam. The Politics of Chinese Language and Culture: The Art of Reading Dragons, London and New York: Routledge, 1998.

JIN Ha. A Free Life, New York: Vintage International, 2009 [2007].

"Exiled to English." In Sinophone Studies: A Critical Reader, edited by Shu-mei Shih, Chienhsin Tsai, and Brian Bernards, 117-24, New York: Columbia University Press, 2013.

The Crazed, London: Vintage, 2002.

“The Language of Betrayal." In The Writer as Migrant, 31-60, Chicago and London: The University of Chicago Press, 2008.

KONG Belinda. Tiananmen Fictions Outside the Square, Philadelphia: Temple University Press, 2012.

KONG Shuyu. "Diaspora Literature." In The Columbia Companion to Modern East Asian Literature, edited by Joshua Mostow, Kirk Denton, Bruce Fulton, and Sharalyn Orbaugh, 546-53, New York: Columbia University Press, 2003.

"Ma Jian and Gao Xingjian: Intellectual Nomadism and Exilic Consciousness in Sinophone Literature." Canadian Review of Comparative Literature 41, no. 2 (2014): 126-46.

LI Melody Yunzi. "Home and Identity en Route in Chinese Diaspora - Reading Ha Jin's A Free Life." Pacific Coast Philology 49, no. 2 (2014): 203-20.

MA Jian. The Dark Road. Translated by Flora Drew, London: Chatto \& Windus, 2013.

. Rou zhi tu 肉之土 (Beijing coma), Taibei: Yunchen wenhua, 2010.

. Yin zhi dao 陰之道 (The dark road), Taibei: Yunchen wenhua, 2012.

“Zhongguo wenxue de queshi--dalu he haiwai hanyu wenxue de chujing” 中國文學的缺

失--大陸和海外漢語文學的處境 (What is missing in Chinese literature: Mainland literature and overseas Chinese writing). Boxun, 2000. http://blog.boxun.com/hero/majian/12_1.shtml.

Retrieved April 23, 2016.

PESARO Nicoletta. “Authorship, Ideology, and Translation: The Case of Ma Jian.” In The Ways of Translation, edited by Nicoletta Pesaro, 161-74, Venice: Cafoscarina, 2013.

"Ma Jian, bambini negati lungo lo Yangtze" (Ma Jian, denied babies along the Yangtze). Il Manifesto, March 29, 2015. http://ilmanifesto.info/ma-jian-bambini-negati-lungo-lo-yangtze/. Retrieved April 23, 2016. 
PICKETT Brent. “Foucault and the Politics of Resistance.” Polity 28, no. 4 (1996): 445-66.

\section{NOTES}

1. Furio Colombo and Gian Carlo Ferretti, L'ultima intervista di Pasolini (Pasolini's last interview), (Roma: Avagliano, 2005), p 53. Unless otherwise specified, the translations are by the author of the article.

2. Belinda Kong, Tiananmen Fictions Outside the Square, (Philadelphia: Temple University Press, 2012).

3. Peter Damgaard, "Visions in Exile. Inroads to a 'Counter-System' of Contemporary Chinese Literature," Literature, University of Copenhagen, Faculty of Humanities, 2012.

4. Ma Jian 馬建, Rou zhi tu 肉之土 (Beijing coma), (Taibei: Yunchen wenhua, 2010).

5. Ha Jin, The Crazed, (London: Vintage, 2002).

6. Ma Jian 馬建, Yin zhi dao 陰之道 (The dark road), (Taibei: Yunchen wenhua, 2012).

7. Ha Jin, A Free Life, (New York: Vintage International, 2009 [2007]).

8. Michel Foucault, "The Subject and Power," in Michel Foucault: Beyond Structuralism and Hermeneutics, (Chicago: The University of Chicago Press, 1982), 208-26.

9. Shuyu Kong, "Diaspora Literature," in The Columbia Companion to Modern East Asian Literature, ed. Joshua S. Mostow et al., (New York: Columbia University Press, 2003), 550. 10. Shuyu Kong, "Ma Jian and Gao Xingjian: Intellectual Nomadism and Exilic Consciousness in Sinophone Literature," Canadian Review of Comparative Literature 41, no. 2 (2014): 127.

11. Haomin Gong, "Language, Migrancy, and the Literal: Ha Jin's Translation Literature," Concentric: Literary and Cultural Studies 40, no. 1 (2014): 151.

12. Michel Foucault, “The Subject and Power," 212.

13. Ma Jian 馬建, “Zhongguo wenxue de queshi--dalu he haiwai hanyu wenxue de chujing” 中國文學的缺失--大陸和海外漢語文學的處境 (What is missing in Chinese literature: Mainland literature and overseas Chinese writing), Boxun, 2000, http:// blog.boxun.com/hero/majian/12_1.shtml. Retrieved April 23, 2016.

14. Ibid.

15. The translation of Ma Jian's works revealed a number of adaptations, performed by Flora Drew in order to tailor the original text to the Western readership. For a more detailed analysis, see Nicoletta Pesaro, "Authorship, Ideology, and Translation: the Case o f Ma Jian," in The Ways of Translation, ed. Nicoletta Pesaro, (Venice: Cafoscarina, 2013), $161-74$.

16. Hodge and Louie pointed out that the longstanding subjugation of Chinese language to Chinese political power caused a progressive mutation of the former according to the needs of the latter. Political discourse has shaped grammar and linguistic forms, resulting in an inextricable interrelation between the two entities. Bob Hodge and Kam Louie, The Politics of Chinese Language and Culture: The Art of Reading Dragons, (London and New York: Routledge, 1998), 96.

17. Ha Jin, "Exiled to English," in Sinophone Studies: a Critical Reader, ed. Shu-mei Shih, Chien-hsin Tsai and Brian Bernards, (New York: Columbia University Press, 2013), 119. 18. Ha Jin, "The Language of Betrayal," in The Writer as Migrant (Chicago and London: The University of Chicago Press, 2008), 32.

19. Michel Foucault, “The Subject and Power," 216. 
20. Nicoletta Pesaro, "Ma Jian, bambini negati lungo lo Yangtze" (Ma Jian, denied babies along the Yangtze), Il Manifesto, March 29, 2015, http://ilmanifesto.info/ma-jian-bambininegati-lungo-lo-yangtze/. Retrieved April 23, 2016.

21. Ibid.

22. Melody Yunzi Li, "Home and Identity en Route in Chinese Diaspora - Reading Ha Jin's A Free Life," Pacific Coast Philology 49, no. 2 (2014): 209.

23. Howard Caygill, On Resistance: A Philosophy of Defiance (London and New York: Bloomsbury, 2013), 97-98.

24. Ibid., 98.

25. Michel Foucault, "La volonté de savoir" (The will to knowledge), in Histoire de la sexualité, vol. 1, (Paris: Gallimard, 1976), 124.

26. Ma Jian, The Dark Road, trans. by Flora Drew, (London: Chatto \& Windus, 2013), 260.

27. Michel Foucault, "La volonté de savoir," 126.

28. Ha Jin, A Free Life, 235. The italics is present in the original text and indicates that the sentences are uttered in Chinese.

29. Ibid., 423.

30. Ma Jian, The Dark Road, 113-14.

31. Ibid., 303.

32. Ha Jin, A Free Life, 83.

33. Ma Jian, The Dark Road, 303.

34. Brent Pickett, "Foucault and the Politics of Resistance," Polity 28, no. 4 (1996): 462.

35. Ma Jian, The Dark Road, 359.

36. Ha Jin, A Free Life, 619.

37. Ibid., 591.

38. Alain Brossat, "Résistance(s) et pouvoir(s) chez Michel Foucauld [sic]" (Resistance(s) and power(s) for Michel Foucault), in Résistances et transferts, ed. Patrick Chemla, 2004, 116-17.

39. Michel Foucault, "La volonté de savoir," 127.

40. Kevin Heller, "Power, Subjectification and Resistance in Foucault," SubStance 25, no. 1 (1996): 99.

\section{ABSTRACTS}

Ha Jin and Ma Jian are two amongst the most representative authors of the so-called Chinese 'diaspora literature,' whose dissident attitude towards the Mainland resulted in them living in exile. The two authors' opposition to the Motherland took different shapes, which are not only displayed through overt criticism, but also translate into an interiorised conflict. This study aims to reveal how the issue of resistance to the Motherland concretises itself in the authors' artistic choices. It will also illustrate how it is represented in their literary creations by comparing their novels A Free Life, by Ha Jin, and The Dark Road, by Ma Jian. Moving from Foucault's reflections on power and resistance, this essay first analyses how Ha Jin and Ma Jian embody two ways of resisting China. It then compares the authors' fictional representations of resistance to one's 
Motherland, revealing the multiplicity of levels at which power can shape the individual's identity.

Ha Jin et Ma Jian sont parmi les auteurs les plus représentatifs de la littérature chinoise dite 'de la diaspora', dont l'attitude subversive vis-à-vis de la Chine continentale leur a coûté l'exil. Leur opposition à la patrie a pris des formes différentes, dont la représentation n'est pas limitée à la critique ouverte, mais se traduit également par un conflit intériorisé. L'étude révèle comment le problème de la résistance à sa patrie se concrétise dans les choix artistiques des deux auteurs, et comment il est représenté par le biais de leur création littéraire, en comparant les romans A Free Life, par Ha Jin, et The Dark Road, par Ma Jian. En nous appuyant sur les réflexions concernant la résistance et le pouvoir élaborées par Foucault, cet article analyse d'abord comment Ha Jin et Ma Jian incarnent deux manières divergentes de résister à la Chine et, ensuite, il compare leurs représentations fictionnelles de la résistance à sa patrie, en révélant ainsi les plusieurs niveaux auxquels le pouvoir peut modeler l'identité individuelle.

\section{AUTHOR}

\section{MARTINA CODELUPPI}

Is a Ph.D. student in comparative literature at Université Sorbonne Nouvelle - Paris 3 in cosupervision with Ca' Foscari University of Venice. Her research deals with contemporary Chinese literature and her project envisages an analysis of the polyglossia characterising contemporary Chinese fiction at a global level, using a transnational and cross-language perspective. She received her M.A. in Interpreting and Translation from Ca' Foscari University of Venice with a thesis in literary translation, and specialised in contemporary Chinese literature through research visits to Peking University (P.R.C.). Other research interests include Translation Studies, Critical Discourse Analysis and narrative theory. 